\title{
Hydrologic interactions of infaunal polychaetes and intertidal groundwater discharge
}

\author{
Ryan K. Dale, Douglas C. Miller* \\ University of Delaware, College of Marine and Earth Studies, 700 Pilottown Rd Lewes, Delaware 19958, USA
}

\begin{abstract}
Groundwater discharge is a common phenomenon along sandy coasts. At Cape Henlopen, Delaware, USA, it creates low porewater salinity in spatially heterogeneous patterns over 1 to $10 \mathrm{~m}$ horizontally. In the present study, porewater salinity and macrofaunal communities were sampled along intertidal transects in summer and spring. We consistently observed high spatial variability in porewater salinity at $10 \mathrm{~cm}$ sediment depth, with changes up to $15.8 \mathrm{~m}^{-1}$. Community composition and species abundance differed between the seasons, but, in each season, communities associated with low porewater salinity $(<15)$ differed from those associated with higher porewater salinity (15 to 24 or $>24$ ). In general, species from a diverse pool of sand flat species gradually became absent as salinity decreased. These local community changes correlated with porewater salinity could compromise the interpretation of various benthic indices that are based on watercolumn salinity, which, at this site, remains around 28. In most samples, the polychaete Marenzelleria viridis was numerically dominant (up to $10000 \mathrm{~m}^{-2}$ ) in burrows up to $50 \mathrm{~cm}$ deep. Both in the field and in cores constructed in the laboratory, we found that the number of worm burrows was highly correlated with hydraulic conductivity of the sediment. We propose that burrowing worms (especially $M$. viridis) at this groundwater discharge site act as hydraulic ecosystem engineers by means of their burrowing and tube building. In general, there appear to be strong physical-biological interactions among the distribution of organisms, their infaunal behavior, the hydrological properties of the sediment and the magnitude of groundwater discharge that may contribute to infaunal zonation on intertidal sand flats.
\end{abstract}

KEY WORDS: Benthic communities - Groundwater - Salinity - Species distribution · Intertidal · Hydraulic conductivity

Resale or republication not permitted without written consent of the publisher

\section{INTRODUCTION}

Many environmental factors have been found to affect the distribution of soft-bottom intertidal communities. Large-scale studies of communities along estuarine gradients show a positive correlation between biodiversity and salinity (Holland et al. 1987, Jorcin 1999, Ysebaert et al. 2003, Gimenez et al. 2005). At a single site, species distribution can be affected by environmental factors such as grain size (Fernandes \& Soares-Gomes 2006), rate of sedimentation (Anderson et al. 2004), beach elevation and morphology (McLachlan \& Jaramillo 1995), and aperiodic weather-driven tidal events (Brazeiro \& Defeo 1996).

Recent attention has been called to the effects of fresh groundwater discharge in soft-bottom intertidal regions (Miller \& Ullman 2004, Zipperle \& Reise 2005, Dale \& Miller 2007). Fresh groundwater discharge occurs wherever an aquifer with positive head pressure is connected to surface water via porous sediment, and these conditions are relatively common worldwide (Zektzer et al. 1973, Bokuniewicz et al. 2003). The total, global groundwater discharge volume of freshwater is estimated to be $10 \%$ that of riverine inputs (Zektzer et al. 1973), and the effect of groundwater discharge on local porewater salinity can be dramatic, both spatially and temporally. In an intertidal groundwater seep zone, porewater salinity can range from 1 to 28 in several meters of horizontal distance across a sand flat (Dale \& Miller 2007), and, over time, porewater salinity at a single point can vary from 2.6 to 28.5 seasonally (Miller \& Ullman 2004). Thus, groundwater discharge creates 
spatial and temporal variability in porewater salinity, with magnitudes similar to those well-known to affect benthic organisms in estuaries (Holland et al. 1987, Jorcin 1999, Ysebaert et al. 2003, Gimenez et al. 2005). In contrast to the typical estuarine salinity gradients over 1 to $100 \mathrm{~km}$, however, the spatial changes in salinity at our study site at Cape Henlopen, Delaware, USA, occur on scales of 1 to $100 \mathrm{~m}$.

Previous work has associated groundwater discharge with the distribution of epibenthic macrofauna over 100s of meters (Kohout \& Kolipinski 1967), reduction of coral density and species richness (Lirman et al. 2003), reduction of seagrass community diversity (Kamermans et al. 2002), and a shift in dominant polychaete species over as little as $5 \mathrm{~m}$ (Zipperle \& Reise 2005). Porewater salinity affects the distribution of harpacticoid copepods along with other environmental factors like sediment size, exposure, water saturation, and oxygen penetration (Moore 1979).

In the present study, we characterized the macroinfaunal communities at a site with known groundwater discharge in 2 different seasons and relate infaunal abundances and community structure to patterns in salinity - an indicator of fresh groundwater discharge - all within the context of the known spatiotemporal variability of groundwater discharge at this site (Dale \& Miller 2007).

The interaction between groundwater discharge and benthic communities may not be a straightforward relationship, however. Jones \& Jago (1993) found that the lugworm Arenicola marina, the burrowing amphipod Corophium arenarium, and the terebellid polychaete Lanice conchilega all increased porosity of the sediment at some, but not all, sites where they were present. We hypothesized that burrows formed at our study site by the highly abundant spionid polychaete Marenzelleria viridis increase the hydraulic conductivity of the sediment. At this site, with known groundwater discharge, increased hydraulic conductivity could potentially promote groundwater discharge and therefore affect local salinity patterns. We tested this hypothesis using measurements from the field as well as subsequent laboratory experiments.

\section{MATERIALS AND METHODS}

Study site. All samples were collected from the intertidal sand flats on the Delaware Bay side of Cape Henlopen, Delaware, USA, on spring low tides. Both the benthos (Bianchi 1988, Miller 1992, Bock \& Miller 1995, Muir 2002) and groundwater discharge (Ullman et al. 2003, Miller \& Ullman 2004, Dale \& Miller 2007, Hays \& Ullman 2007) have been studied at this site. The shoreline topography is characteristic of estuarine beaches (Nordstrom 1992), with a steep slope and a sharp break in slope from where the sand flat extends bayward. The position of this slope break moves onand offshore relatively little $( \pm 1 \mathrm{~m}$ over a year) and served as a benchmark. Sand bars are typically found between $\sim 10$ and $25 \mathrm{~m}$ offshore of the break in slope, and the positions vary from month to month (Muir 2002). The typical surface median grain size of this site ranges from 0.25 to $0.5 \mathrm{~mm}$ (Muir 2002). To prevent tidal exposure time from confounding results, our sampling avoided the seaward sandbars, and samples were only taken from the flat portion of the sand flat shoreward of the sand bars. This flat region had a small $( \pm 5 \mathrm{~cm})$ range in height, corresponding to $\pm 10 \mathrm{~min}$ exposure time as determined by observation of rising and falling tides and inspection of records from a NOAA CO-OPS tide gauge located $2 \mathrm{~km}$ west of our site (Stn 8557380, Lewes, Delaware).

Macrofaunal transects. Benthic macrofaunal communities and porewater salinity were sampled on spring low tides in August and September 2005 (hereafter termed summer) and May and June 2006 (hereafter termed spring). Porewater salinity at $10 \mathrm{~cm}$ sediment depth was measured using porewater wells and syringes as described in Miller \& Ullman (2004). Salinity of the porewater collected in the syringe was measured with a handheld salinometer (YSI Model 30).

Preliminary porewater salinity measurements were used to locate transects for macrofaunal coring. Porewater salinity on or beyond the sand bars is typically $\sim 28$ and similar to the surface water at this site (e.g. Sharp et al. 1982), but, closer to shore, porewater salinity is variable and can be as low as 0.1 (Dale \& Miller 2007). Since there is well-characterized variation in salinity across the first $25 \mathrm{~m}$ from the benchmark (Dale \& Miller 2007), we chose to sample along transects perpendicular to shore to capture the expected salinity gradient, taking care to select areas of the sand flat that did not appreciably vary in elevation. Based on previous experience at this field site (Dale \& Miller 2007), we selected our transects specifically so that one endpoint was $<15$ salinity and the other endpoint was $>24$. Often, salinities were lower in the middle of a transect than they were at the $<15$ endpoint, resulting in a wider range than 15 to 24 . To capture the salinity gradient, if consecutive porewater salinities within a transect differed by $>8$, an intermediate porewater sample was then taken at the midpoint. These a priori salinity criteria were used for all transects. Table 1 describes the transects in terms of date, season, salinity range, spacing, number of cores, distance, and descriptive statistics. Because lower salinities are found farther offshore in spring (Miller \& Ullman 2004; Figs. 1 \& 2), we extended the spring transects so that they covered a greater distance than those in summer. 
Table 1. Transect sampling dates, number of cores, spacing and salinity ranges

\begin{tabular}{|c|c|c|c|c|c|c|c|}
\hline Transect & Date & $\begin{array}{l}\text { Spacing } \\
\text { (m) }\end{array}$ & $\begin{array}{l}\text { No. of } \\
\text { cores }\end{array}$ & $\begin{array}{l}\text { Distance from } \\
\text { benchmark (m) }\end{array}$ & $\overline{\text { Min. }}$ & $\begin{array}{l}\text { Salinity } \\
\text { Max. }\end{array}$ & Mean \\
\hline \multicolumn{8}{|c|}{ Summer $2005(N=39)$} \\
\hline $\mathrm{T} 1$ & 17 Aug & 0.5 & 10 & $0-4.5$ & 11.6 & 26.9 & 18.2 \\
\hline $\mathrm{T} 2$ & 18 Aug & 0.5 & 11 & $0-5$ & 3.5 & 26.1 & 18.8 \\
\hline T3 & $17 \mathrm{Sep}$ & 0.5 & 4 & $0-2$ & 8.1 & 24.3 & 12.0 \\
\hline $\mathrm{T} 4$ & $18 \mathrm{Sep}$ & $0.5-1$ & 14 & $4-14$ & 11.5 & 27.6 & 19.9 \\
\hline \multicolumn{8}{|c|}{ Spring $2006(\mathrm{~N}=49)$} \\
\hline T6 & 26 Apr & $1-2$ & 11 & $0-20$ & 3.3 & 28.6 & 17.1 \\
\hline $\mathrm{T} 7$ & 27 Apr & 1 & 15 & $0-14$ & 8.3 & 28.5 & 18.2 \\
\hline T8 & 25 May & $1-2$ & 10 & $2-18$ & 12.6 & 28.0 & 20.2 \\
\hline T9 & 26 May & $1-2$ & 13 & $2-22$ & 10.2 & 29.2 & 22.9 \\
\hline
\end{tabular}
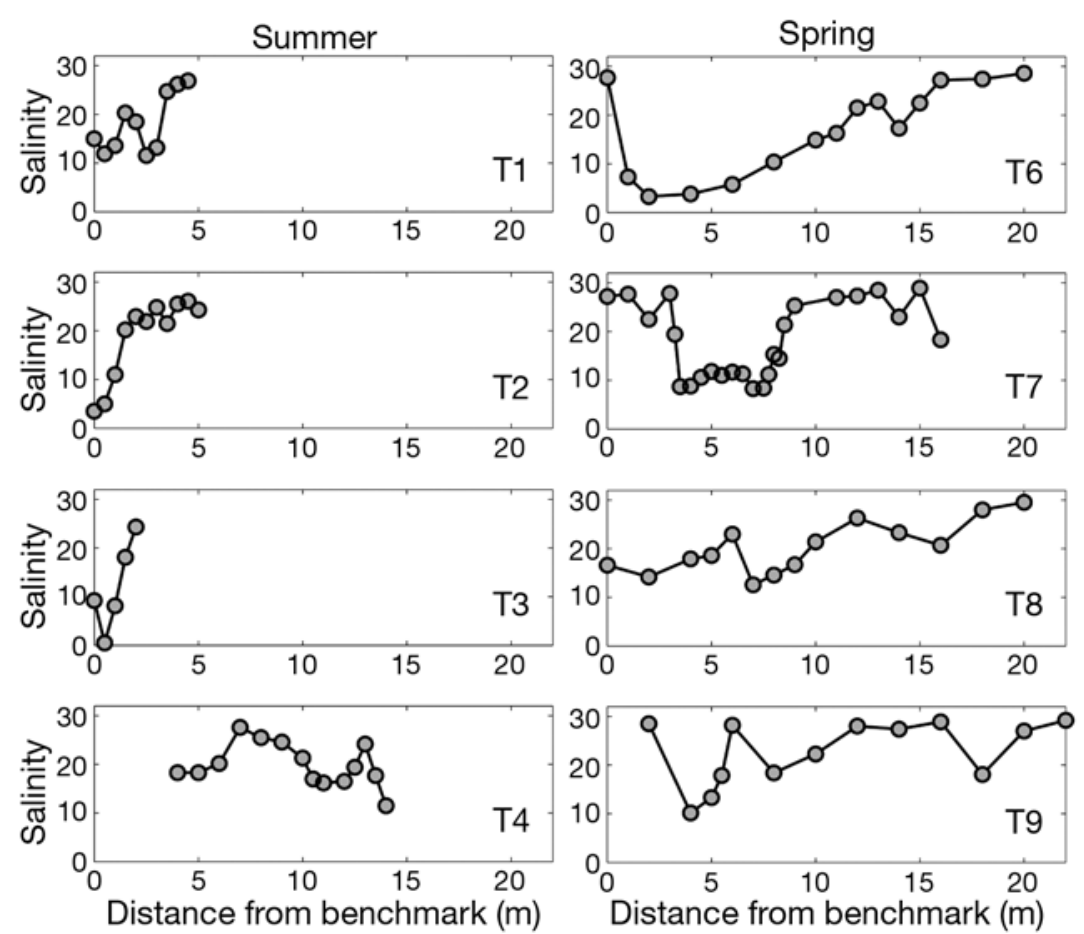

Fig. 1. Porewater salinity at $10 \mathrm{~cm}$ sediment depth along transects in summer (T1 to T4) and spring (T6 to T9)
After all porewater wells in the transect were sampled, a $10 \mathrm{~cm}$ diameter core was taken adjacent to each porewater well $(<5 \mathrm{~cm}$ away) to quantify macrofaunal abundance. The sediment was cored down to a depth of at least $40 \mathrm{~cm}$, sieved through $1 \mathrm{~mm}$ mesh for macrofauna, and the retained sample was preserved in formalin for later laboratory analysis. Organisms were identified to genus or species, and the diversity of each core was calculated as $\mathrm{HD}_{1}=\exp \left(H^{\prime}\right)$, where $H^{\prime}$ is the Shannon-Wiener diversity index (Gray 2000). Since the abundance, distance, and salinity data did not come from a bivariate normal distribution, we tested for monotonic correlations using the Spearman rank correlation, $\mathrm{r}_{\mathrm{s}}$ (Quinn \& Keough 2006). Multi-dimensional analyses including ANOSIM (analysis of similarity), NMDS (non-metric multidimensional scaling) ordinations, and diversity indices were performed using the PRIMER-E 5 software package (Plymouth Routines in Marine Ecological Research, Plymouth Marine Lab). Abundance data were 4th-root transformed in order to down-weight the influence of highly abundant species, and the transformed data were used to generate a Bray-Curtis dissimilarity matrix for ANOSIM and NMDS analysis (Clarke \& Warwick 1994, Clarke \& Gorley 2001).

Vertical hydraulic conductivity. To investigate the effect of burrows, particularly those of the highly abundant Marenzelleria viridis, on hydraulic conductivity of the sediment, we estab-
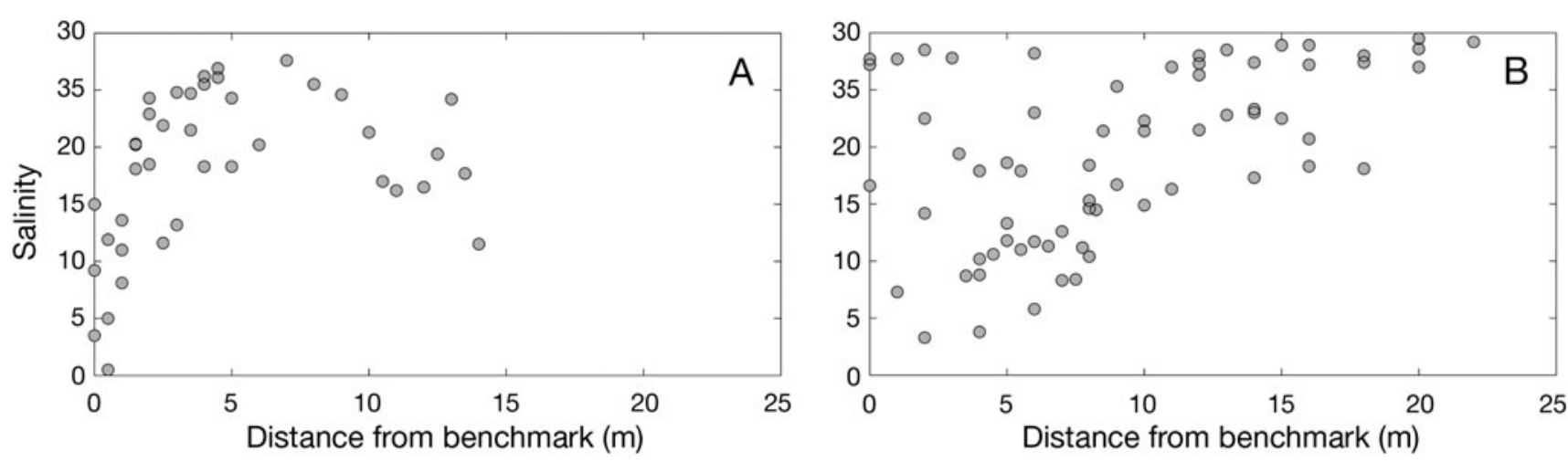

Fig. 2. Porewater salinity at $10 \mathrm{~cm}$ sediment depth grouped to show (A) summer and (B) spring salinities 
lished transects on 22 June 2005 and 15 June 2006, so that they crossed readily apparent patches of $M$. viridis burrows. These transects were $<10 \mathrm{~m}$ from the shore and in the same general region as the macrofaunal transects. Every meter along these transects, porewater salinity was measured (using methods from the macrofaunal transects, above) and cores were taken using a $6.7 \mathrm{~cm}$ diameter butyrate core. Each core was extracted from the sediment, extruded so only the top $15 \mathrm{~cm}$ of sediment remained in the core, and placed on an inverted, $1 \mathrm{~mm}$ mesh sieve resting on the sediment. A known volume of seawater was added to the top of the core, and the time it took for this seawater to fall through the core was used to calculate hydraulic conductivity. Using standard equations for a falling-head permeameter (Fetter 2001), hydraulic conductivity was parameterized as the coefficient $K$, typically having values around $10^{-4} \mathrm{~m} \mathrm{~s}^{-1}$ for medium sands (Fetter 2001). After the timed measurements, the core was then gently twisted apart in the middle, revealing obvious worm burrows often ringed with iron oxide. Burrows were counted by eye and digital images were taken for later verification of burrow counts.

In addition, ten $15 \mathrm{~cm}, 6.7 \mathrm{~cm}$ diameter cores from haphazardly chosen locations were sieved through $1 \mathrm{~mm}$ mesh to determine if individual worms were present in the top $15 \mathrm{~cm}$ of sediment used for the hydraulic conductivity measurements. While burrows were abundant (1 to 25 burrows per core), only 1 or 2 worms were found in each sieved sample, suggesting that most worms burrowed deeper to escape the core (consistent with other observations and our routine coring to $40 \mathrm{~cm}$ for macrofaunal cores, above). Consequently, the field hydraulic conductivity measurements reflected mostly burrows without worms. To determine the relationship between the number of burrows counted and the actual number of worms present in situ, larger and deeper cores $(10 \mathrm{~cm}$ diameter, to $\sim 50 \mathrm{~cm}$ depth) were taken, and the core was incrementally extruded and twisted off to reveal worm burrows through the length of the core. The number of burrows at $10 \mathrm{~cm}$ was used, as the maximum number of burrows was frequently found in the top 10 to $15 \mathrm{~cm}$ of the core. The entire core was sieved, preserved, and sorted as described above to quantify the abundance of worms in the core.

Since the field hydraulic conductivity measurements appeared to only be measuring the effect of empty worm burrows, we made comparable measurements in the laboratory in cores known to have occupied burrows. We filled each of twelve $6.7 \mathrm{~cm}$ diameter core tubes with homogenized, $1 \mathrm{~mm}$ sieved sand taken from the surface $15 \mathrm{~cm}$ of the Cape Henlopen site in September 2007. Each constructed core was between 30 and $40 \mathrm{~cm}$ tall. Marenzelleria viridis individuals were collected and added to 6 of the cores, and the worms immediately started burrowing. The cores were then taken back to the laboratory and kept in 20 ppt seawater for $3 \mathrm{~d}$ with the bottoms capped. Preliminary tests showed that this was an adequate length of time for the worms to form burrows $20+\mathrm{cm}$ deep.

We made triplicate hydraulic conductivity measurements, using the same falling-head permeameter method used in the field, at each of 4 sediment column heights. For each height, the core was incrementally extruded from the bottom such that the top of the core (and the openings to the burrows) remained undisturbed. Worms were observed in their burrows at all core heights. One of these heights was always between 14 and $18 \mathrm{~cm}$, and the 3 measurements for that height were averaged for comparison to the $15 \mathrm{~cm}$ high field data. In some cores, but not all, the burrows appeared to be more branched in the top $5 \mathrm{~cm}$ of the cores. Using the same method as in the field, the laboratory cores were separated at $7.5 \mathrm{~cm}$ sediment core height and the burrows were counted visually. To compare with the deeper field cores taken to correlate the number of worms with the number of burrows, each laboratory core was also sieved and the worm abundance quantified.

\section{RESULTS}

\section{Macroinfaunal transects}

All transects showed high spatial variability in porewater salinity (Fig. 1). Gradients were as sharp as $15.8 \mathrm{~m}^{-1}$ (e.g. T3), but these sharp salinity gradients did not always occur at the same distance from the shore. While summer transects had smaller spacing between points and were generally shorter than the spring transects, all transects encompassed the a priori salinity criteria of $<15$ to $>24$ as intended (Table 1 ). The total salinity in both seasons ranged from $<5$ to 28 such that a full range of estuarine salinities was measured in each season.

Distributions of the 4 most abundant species (Marenzelleria viridis, Paraonis sp., Heteromastus filiformis, and Leitoscoloplos fragilis) varied along both distance (Fig. 3A-D) and salinity (Fig. 3E-H) gradients. The correlation of the response of a single species to distance and salinity varied both by season and by species (Fig. 3). In contrast to the other species, the abundance of Leitoscoloplos fragilis was not monotonically correlated with salinity or distance in either season, but occurred at intermediate salinities closer to shore (Fig. 3D,H).

The communities observed in spring and summer were significantly different (Fig. 4A), despite covering the same range of salinities (Fig. 2). As a result, subsequent analyses were conducted on each season's data 

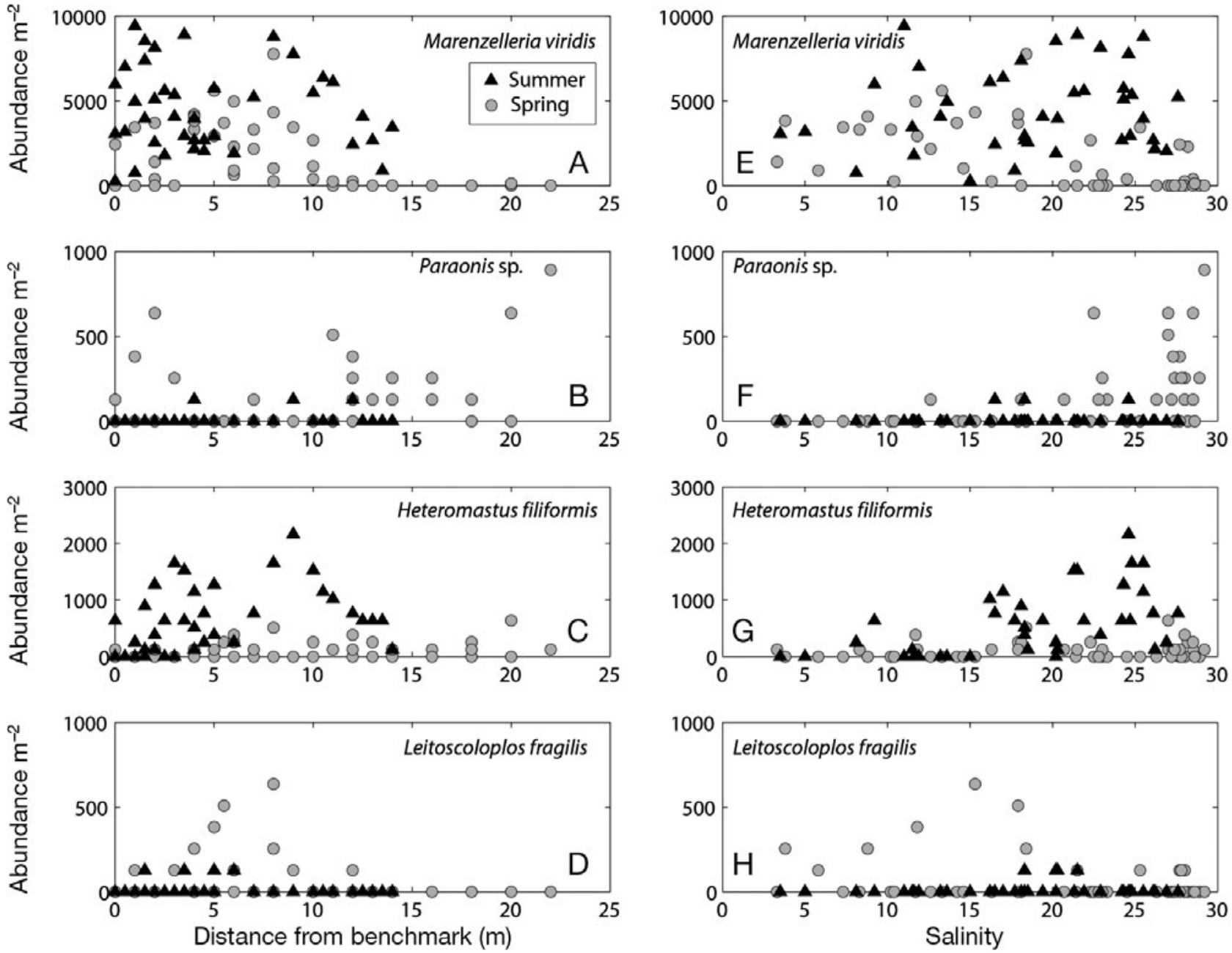

Fig. 3. (A-D) Species abundance plotted against distance from benchmark and (E-H) the same abundance data plotted against salinity. Only the 4 most abundant species are shown. Both summer and spring are shown. Note $y$-axis scales differ by species. The following had significant Spearman's rank correlations compared to a Bonferroni-adjusted $\alpha=0.0031$ ( $\alpha=0.05$ spread among 16 tests). All other relationships were not significant. With distance: Marenzelleria viridis spring $\mathrm{r}_{\mathrm{s}}=-0.55, \mathrm{p}=0.0042 ;$ Heteromastus filiformis summer $\mathrm{r}_{\mathrm{s}}=0.53, \mathrm{p}=0.0004$. With salinity: $M$. viridis spring $\mathrm{r}_{\mathrm{s}}=-0.62, \mathrm{p}<0.0001$; Paraonis sp. spring $\mathrm{r}_{\mathrm{s}}=0.6$, $\mathrm{p}<0.0001 ;$ H. filiformis summer $\mathrm{r}_{\mathrm{s}}=0.57, \mathrm{p}=0.0001 . \mathrm{N}=39$ (summer); $\mathrm{N}=49$ (spring)

separately. In each season, samples were grouped into salinity classes according to our a priori sampling of regions based on end-member values of 15 and 24 . The salinity classes used for the NMDS ordinations and ANOSIM were $<15,15$ to 24 , and $>24$ salinity (Fig. 4B,C). In both seasons, the stress levels (summer = 0.17 ; spring $=0.17$ ) indicate that the 2-dimensional NMDS ordination is an adequate representation of the multi-dimensional pattern in community similarity.

An ANOSIM on the full multi-dimensional dataset showed that communities in the $<15$ salinity class were significantly different from those in both the 15 to 24 and $>24$ salinity classes (Fig. 4B,C). In general, the $<15$ communities consisted of highly abundant Marenzelleria viridis as well as Heteromastus filiformis and Leitoscoloplos fragilis. Communities in salinities $>15$ typically had other species present, but in low abundance compared to $M$. viridis and $H$. filiformis. These highersalinity species included Paraonis sp., Spio setosa, Glycera sp., Streblospio benedicti, Tharyx sp., Pectinaria gouldi, Cerebratulus lacteus, Phyllodoce spp., Spiochaetopterus oculatus, and Illyanassa obsoleta.

The relationships between distance from shore, salinity, biodiversity $\left(\mathrm{HD}_{1}\right)$, and species richness differed between seasons (Fig. 5). In both seasons there was a significant positive correlation of diversity and species richness with distance (Fig. 5). However, the correlation with salinity was only significant in spring, where both diversity and species richness increased with increasing salinity. In particular, there appears to be a threshold in spring where diversity increases sharply at salinities > 25 (Fig. 5B). 

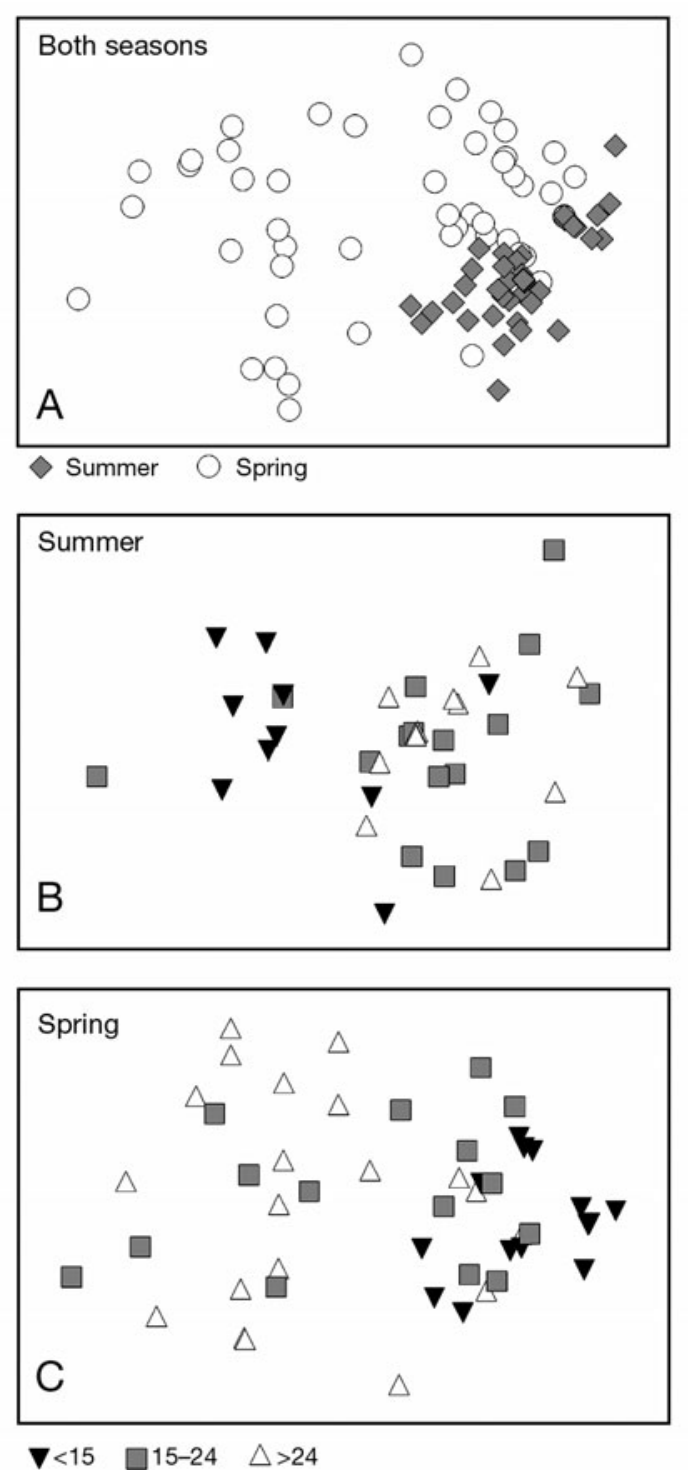

Fig. 4. Non-metric multi-dimensional scaling (NMDS) ordinations of community data. (A) Communities differed significantly between seasons (stress $=0.15, \mathrm{p}<0.001$ [ANOSIM], $\mathrm{N}=$ 88). (B) Summer communities in low salinity $(<15)$ differed from communities in both 15 to 24 and $>24$ salinity classes (stress = $0.17, p=0.005$ and $\mathrm{p}=0.001$, respectively [ANOSIM], $\mathrm{N}=39$ ). (C) Spring communities in low salinity $(<15)$ also differed from communities in both 15 to 24 and $>24$ salinity classes (stress = $0.17, \mathrm{p}=0.001$, in both cases [ANOSIM], $\mathrm{N}=49$ )

\section{Vertical hydraulic conductivity}

Worm burrows were evident in cross-sections of the hydraulic conductivity cores (Fig. 6A). Due to the high abundance of Marenzelleria viridis where these cores were taken, a large fraction of the burrows are expected to be from this species. Burrows were approximately $2 \mathrm{~mm}$ in diameter, and were ringed in iron oxide, presumably from reduced, iron-rich groundwater.
Marenzelleria viridis was often observed in burrows down to $50 \mathrm{~cm}$ in the deeper cores taken to relate worm density to burrow density. Burrow counts from these cores at $10 \mathrm{~cm}$ sediment depth were used to compare to the burrow counts at $7.5 \mathrm{~cm}$ in the hydraulic conductivity measurements (Fig. 6B). As expected, there was a significant positive linear relationship between the number of burrows and the number of $M$. viridis, and this relationship did not differ between the laboratory and field cores (Fig. 6B). However, there were about 1.7 times more worms than burrows observed in a core (Fig. 6B).

There was a significant positive linear relationship between the number of burrows in a core and its hydraulic conductivity in both 2005 and 2006 field samplings, although the slopes differed by year (Fig. 7A). For comparison with the laboratory data, field data were then pooled to examine the effect of presence of worms in burrows, presuming they were absent in the field but noting that worms were directly observed in the laboratory cores. In both the laboratory and field data, hydraulic conductivity significantly increased with the number of burrows, and the slope of the line did not differ between these 2 sets of measurements (Fig. 7B).

Consistent with the distribution of Marenzelleria viridis in relation to salinity in summer (Fig. 3), when these hydraulic conductivity cores were taken, there was no significant monotonic relationship between either porewater salinity and worm burrows $(p=0.18)$ or porewater salinity and hydraulic conductivity $(p=0.53)$.

\section{DISCUSSION}

\section{Individual species responses}

The sampled area of the sand flat had relative elevation changes of $\pm 5 \mathrm{~cm}$, which correspond to differences of approximately $\pm 10 \mathrm{~min}$ in exposure time. The sand flat is exposed typically only on spring tides, and by establishing the transects on relatively flat areas within $20 \mathrm{~m}$ of the beachface, we attempted to minimize the factor of exposure time. In addition, the slope is not always constant, and a distance farther from shore may or may not correspond to greater depth. Although we did not measure beach topography for each transect (but see Dale \& Miller [2007], their Fig. 2, for a representative profile from this site), we believe the change in depth is not large enough to directly alter community structure, and the significant positive correlations we observed between species abundance and distance are simply a reflection of the correlation of salinity and distance from shore. This correlation means that we cannot uniquely resolve these 2 effects, and further work 

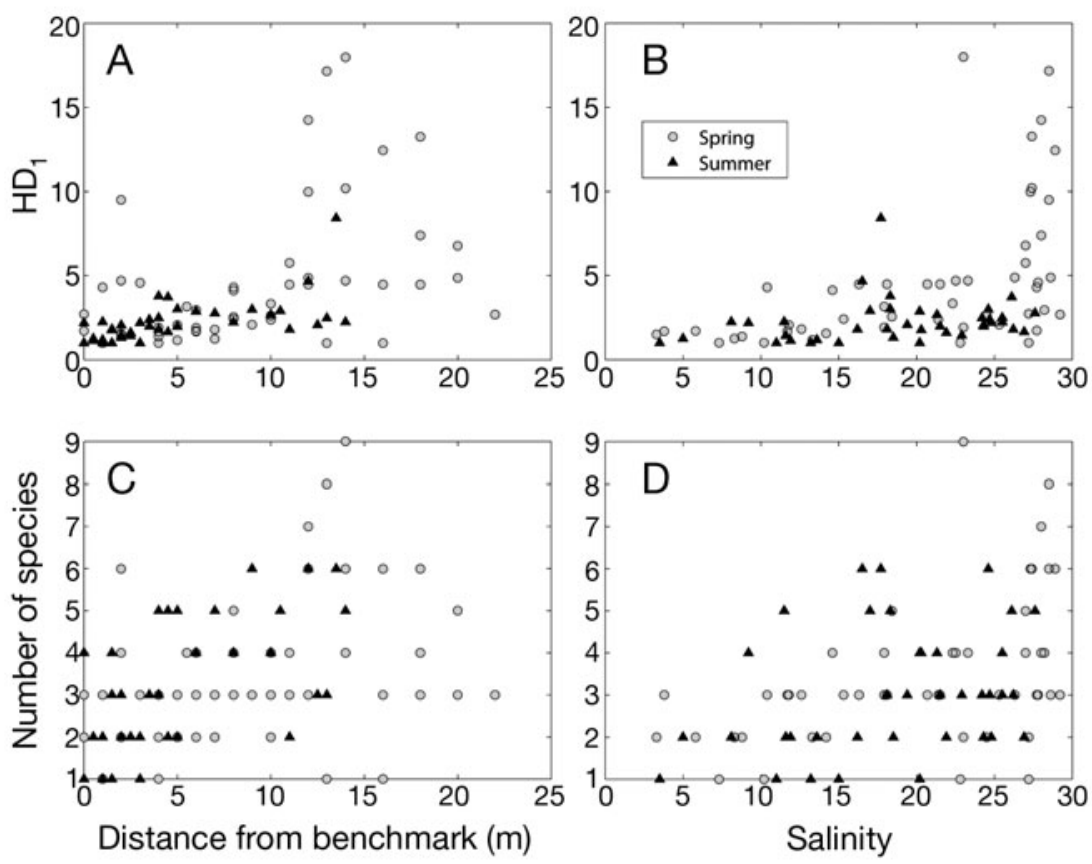

Fig. 5. $(A, B)$ Biodiversity and $(C, D)$ species richness versus $(A, C)$ distance from benchmark and $(B, D)$ salinity. The following had significant Spearman's rank correlations compared to a Bonferroni-adjusted $\alpha$ of 0.006 . All other relationships were not significant. With distance: $H_{1}$ summer, $r_{s}=0.71, p<0.0001$; $\mathrm{HD}_{1}$ spring, $\mathrm{r}_{\mathrm{s}}=0.52, \mathrm{p}=0.0001 ;$ species richness summer, $\mathrm{r}_{\mathrm{s}}=0.64, \mathrm{p}<0.0001$; species richness spring, $\mathrm{r}_{\mathrm{s}}=0.39, \mathrm{p}=0.005 ; \mathrm{HD}_{1}$ spring, $\mathrm{r}_{\mathrm{S}}=0.66, \mathrm{p}<0.0001$; species richness spring, $\mathrm{r}_{\mathrm{s}}=0.52, \mathrm{p}=0.0001 . \mathrm{N}=39$ (summer); $\mathrm{N}=49$ (spring)
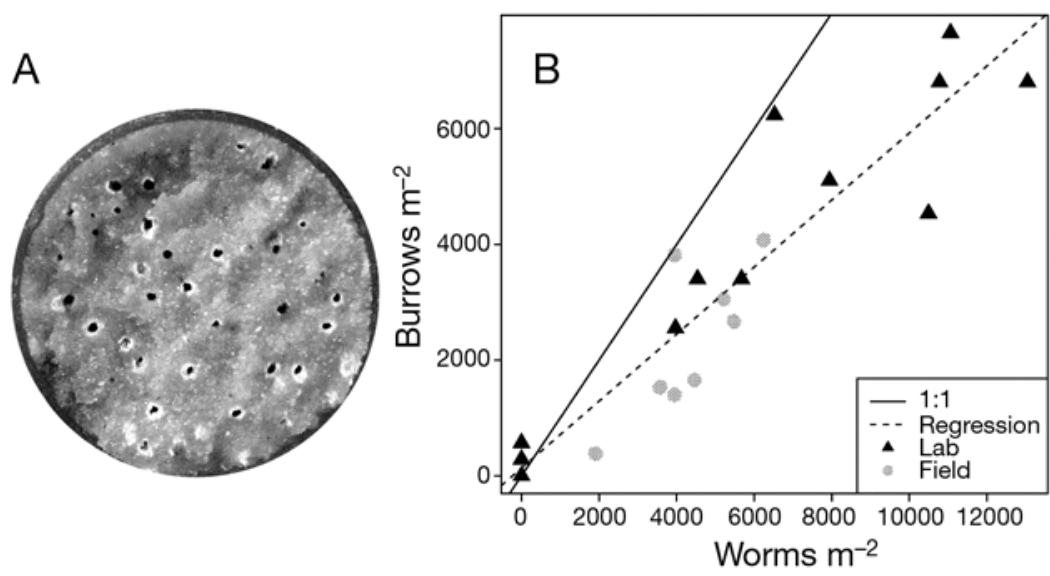

Fig. 6. (A) Gray-scale cross-section of a $6.7 \mathrm{~cm}$ core taken at about $7 \mathrm{~cm}$ sediment depth, showing worm burrows (dark circles). Brightness of the red channel has been increased to highlight rings of iron oxide around the burrows. There are 30 obvious burrows in this core $\left(8509 \mathrm{~m}^{-2}\right)$, but light regions, especially in the lower right quadrant, indicate possible burrows that were crushed by handling the core. Such indeterminate features were not counted in either laboratory or field measurements. (B) In both field and laboratory cores, there were about 1.7 times more Marenzelleria viridis than there were observed burrows. There were no differences in the slopes of the laboratory and field data (ANCOVA, $p=0.17$ ). Pooled regression on all data: $p<0.0001, \mathrm{R}^{2}=0.86$, slope $=0.58, \mathrm{~N}=20$ (e.g. along-shore sampling across low porewater salinity patches) needs to be done to separate the relative contribution of the aforementioned factors to the observed patterns in benthic communities.

The 4 most common species have well-known relationships with salinity, and our results are fully consistent with published studies: Marenzelleria viridis, salinities from 1 to 32 (Bastrop 1997); Heteromastus filiformis, 4 to 32 and median 23 (Ysebaert et al. 2002); Leitoscoloplos fragilis 10 to 30 (Logan \& Maurer 1975); and Paraonis sp., high-salinity sandy sites (Hyland et al. 2004). In our data, each of these species displayed different responses to salinity and distance, and no species was significantly correlated with salinity or distance in both seasons (Fig. 3). The reason for this observed seasonal disparity in response remains unknown, but may be related to developmental stage or seasonal or yearly differences in settlement cues, food, or predation. Regardless, these literature reports, combined with the small scale over which we measured differences in fauna and the apparent uniformity of the sampling area, all support our interpretation of species abundances and community differences in terms of porewater salinity.

By far the most common species was Marenzelleria viridis (see Fig. 3A,E), an observation consistent with prior work at this site (Miller \& Ullman 2004, Dale \& Miller 2007). This species was negatively correlated with salinity (Fig. 3), but was found over a wide range of salinities. The distribution of $M$. viridis over a wide range of salinities during both seasons (Fig. 3, see also Miller \& Ullman 2004) suggests a wide salinity tolerance for this species, a conclusion that is supported by previous work (Bastrop 1997).

The behavior of a species will influence the degree to which its distribution is affected by groundwater. Leitoscoloplos fragilis, which has been described as a discretely motile species (Brown 1979), showed peak abundances between 5 and $10 \mathrm{~m}$ from 

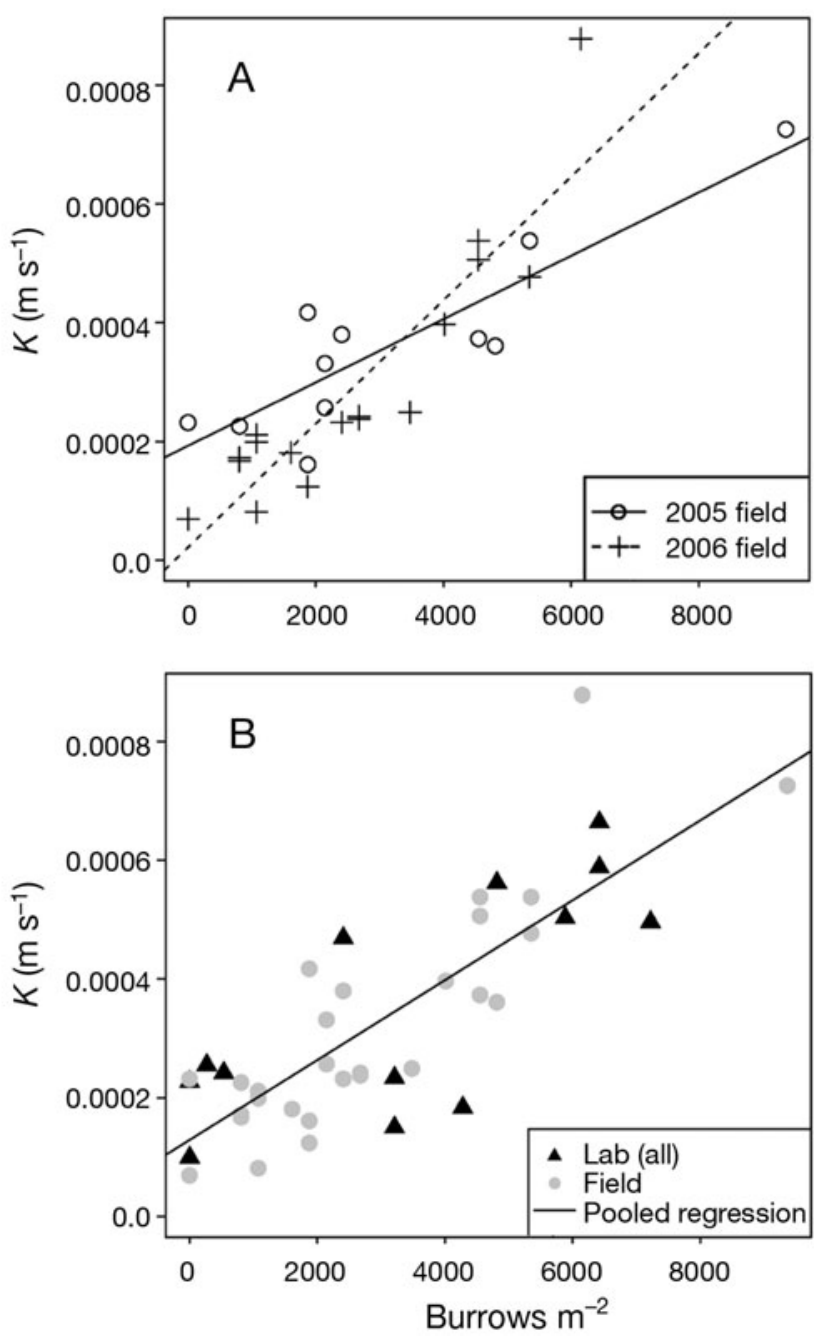

Fig. 7. (A) Relationship between hydraulic conductivity $(K)$ and burrow density differed between 2005 and 2006 (ANCOVA, $\mathrm{p}=0.004)$, but, in each year, there was a significant positive linear relationship: 2005 regression: $\mathrm{R}^{2}=0.75, \mathrm{p}=$ 0.0003 , slope $=5.3 \times 10^{-8}, \mathrm{~N}=11 ; 2006$ regression: $\mathrm{R}^{2}=0.81, \mathrm{p}$ $<0.0001$, slope $=1.0 \times 10^{-7}, \mathrm{~N}=17$. (B) Relationship between $K$ and burrow density did not differ significantly between the pooled field data where no worms were assumed to be present in burrows and the laboratory data where worms were known to be present in burrows (ANCOVA, $\mathrm{p}=0.17$ ). $K$ significantly increased linearly as a function of burrow density in both laboratory and field measurements. Pooled regression on all data: $\mathrm{p}<0.0001, \mathrm{R}^{2}=0.66$, slope $=6.7 \times 10^{-8}, \mathrm{~N}=41$

the benchmark around a salinity of 15 (Fig. 3D,H). The peak in both distance and salinity plots seems surprisingly clear. If $L$. fragilis moves in response to porewater salinity, the distribution of this species at a single sampling time will more closely match the point measurements made at that time. In contrast, if the distribution of a sedentary species is affected by salinity, the distribution at any 1 sampling time reflects an integration of changing salinities over the lifetime of individu- als. Given the highly variable porewater salinity at Cape Henlopen, the resulting distribution of a sedentary polychaete may not have a clear pattern when related to salinity measured at a single time point. In other words, 2 species that respond identically to salinity, but differ in their mobility, could well exhibit different distributions in an environment where salinity changes over time. Furthermore, deep-burrowing species may experience different salinity regimes than shallow-living species, since salinity tends to decrease with depth in sediment. Behavior within the burrow matters as well, and the amount of time spent at each depth will differ by species. For example, a deepburrowing but surface deposit feeder like Marenzelleria viridis may not spend as much time at low-salinity depths as a deep-burrowing, head-down subsurface deposit feeder like Arenicola marina. While outside the scope of the present study, the behavior of an individual species is clearly important to understanding its response to groundwater discharge.

\section{Community responses}

Community composition differed between seasons (Fig. 4A). Since the spring and summer sampling efforts were in different years, the communities in the 2 seasons came from different recruitment events. An interannual difference could be caused by any number of factors, including larval supply, predation, chemical cues, competition, or natural seasonal population cycles (Qian 1999). Without sampling several consecutive seasons, it is impossible to tell whether the differences we observed between spring and summer communities were due to intra- or inter-annual variation.

Regardless of the cause, and despite the differences between seasons (Fig. 4A) and between individual species responses (Fig. 3), the NMDS ordinations and the ANOSIM show that response of the community to porewater salinity was seasonally consistent (Figs. 4B,C \& 5). In both seasons, communities associated with lower salinity $(<15)$ were different from those associated with salinities $>15$. Closer inspection of the data showed that there appeared to be a pool of 'sand flat species', composed of the species found at salinities $>24$ in spring, but there did not seem to be a different pool of 'seep species' that only occurred at lower salinities. Rather, the assemblage at lower salinities was a subset of the high-salinity assemblage, where species from the sand flat pool gradually dropped out (e.g. Paraonis sp. in spring and Heteromastus filiformis in summer) as salinity decreased, resulting in lower diversity. This is consistent with the 2-ecocline model of an estuarine ecosystem (Attrill \& Rundle 2002), which states that freshwater species and marine species intrude into intermediate salinities, with 
each group decreasing in diversity as salinities become more stressful and resulting in a region of overall low diversity. We did not observe a high-diversity community associated with the lowest salinity locations, indicating that the groundwater discharge zone at Cape Henlopen only represents the marine side of the 2-ecocline model. This may be because the porewater does not remain low for long enough periods of time, or freshwater species may have a difficult time colonizing local areas of low porewater salinity with overlying high-salinity water.

Our study complements and further extends a previous study from Sylt in northern Germany (Zipperle \& Reise 2005) by sampling at a site with well-studied spatio-temporal patterns in groundwater discharge (Ullman et al. 2003, Miller \& Ullman 2004, Dale \& Miller 2007, Hays \& Ullman 2007), with different species assemblages (Bianchi 1988, Bock \& Miller 1999, Muir 2002) and in 2 different seasons. The Cape Henlopen site had a smaller grain size at the surface and smaller silt/clay fraction than the Sylt site, and the sand flat at Cape Henlopen does not extend as far from the beachface (or shoreline) as that at Sylt (20 m compared to $200 \mathrm{~m}$ ). Comparing Fig. 2 in Zipperle \& Reise (2005) to the results reported by Dale \& Miller (2007), it also appears that the patterns in groundwater discharge at Sylt may be on a larger scale than those at Cape Henlopen. Our results do not show species distributions differing as clearly as did those for Nereis spp. and Arenicola marina at Sylt, suggesting that other factors are at work at Cape Henlopen, but both studies show responses that differ by species over short (5 to $10 \mathrm{~m}$ ) distances. At the community level, both studies show decreased species richness and diversity at lower porewater salinities. In addition, our study shows that, while the abundance of individual species can change, the relative ratios of species in the community (biodiversity) are consistent between seasons or years.

Previous work shows the general pattern of low diversity, where salinity is intermediate or widely varying over the length of an estuary (Holland et al. 1987, Jorcin 1999, Ysebaert et al. 2003, Gimenez et al. 2005). It is possible that the increased diversity we saw at higher salinities is, in fact, due to the reduced salinity variability at those locations rather than the absolute salinity (Attrill 2002). Measuring the effect of salinity variation on community composition would require time series of porewater salinity at each location. Given the high spatial heterogeneity at this site (Dale \& Miller 2007) and the mobility of some species (discussed above), this would require a careful sampling design to investigate further, but would be explicitly testable against Attrill's (2002) model.

Benthic indices, which employ benthic communities as indicators for the environmental quality of a study site, often rely on diversity indices like the Shannon-
Wiener index. These indices typically compensate for known gradients of diversity as a function of salinity (Zettler et al. 2007). To qualify as a 'good' or 'pristine' site, a low-salinity study site has a lower diversity threshold than a corresponding high-salinity site. Indices like the Chesapeake B-IBI (benthic index of biological integrity; Weisberg et al. 1997) use parameters including biomass, abundance of pollution-sensitive taxa (of which Marenzelleria viridis is a member), biomass of pollution-indicative taxa (including Leitoscoloplos fragilis), the Shannon-Wiener index, and others, with the set of parameters to be used depending on the salinity class of a site. If surface water alone were measured at Cape Henlopen (typically around 28; Sharp et al. 1982), the seepage zone on the sand flat would be classified as a polyhaline sand site according to the Chesapeake Bay B-IBI. On the other hand, if porewater were measured, the same site would be considered low mesohaline. Two differing benthic scores could be obtained from the same sample, depending on which salinity class was used. We suggest that, in the development of benthic indices, porewater salinity should be considered as a measured parameter to avoid erroneously classifying habitat quality.

\section{Vertical hydraulic conductivity}

Our data strongly indicate an interaction between groundwater hydrology and the benthic infaunal community, and thus hydrological studies should consider the effects of benthic ecology on groundwater discharge. The ability of worm burrows to increase hydraulic conductivity of the sediment (Fig. 7) could lead to greater groundwater discharge, and greater groundwater discharge can, in turn, lead to a higher abundance of low-salinity-preferring or low-salinitytolerant organisms. If these low-salinity-preferring organisms affect hydraulic conductivity in some way, favorable lower salinity may increase, forming a positive feedback loop.

However, we did not observe any significant correlation between either burrow density and salinity or hydraulic conductivity and salinity (see 'Results'). We see 3 potential reasons for this that could act alone or in combination. First, the hydraulic conductivity of the surface sediment (the top $15 \mathrm{~cm}$ that we measured) may not be a determinant of discharge if flow is controlled by deeper, less permeable sediment layers. Second, there could be sampling artifacts associated with insertion of the $2.5 \mathrm{~cm}$ diameter porewater wells and/or sampling only at low tide, in which salinity lags tidal level (Fig. 6 in Dale \& Miller 2007). Third, increased conductivity permits greater mixing of salty 
surface water into the sediment. The porewater salinity we measured at $-10 \mathrm{~cm}$ may thus be more a function of the degree of mixing that occurred over the previous tidal cycle than the magnitude of groundwater discharge at the time of measurement. Indeed, the lack of an observed relationship between Marenzelleria viridis and salinity (Fig. 3) may, in part, be due to this confounding effect. Sampling throughout the tidal cycle or direct measurement of discharge (e.g. using miniature drum-type seepage meters) may clarify any direct relationship of conductivity and salinity (or even worm burrow behavior, see above) at times of low tide.

While our data show a clear trend in which hydraulic conductivity increases 10 -fold over the typical range of worm abundances, it is difficult to estimate the true in situ permeability, since active or remnant burrows were probably missed by the unaided eye or were collapsed in the process of extracting the core. This is supported by our observation that there were more worms in a core than observed burrows (Fig. 6B), suggesting that either multiple worms inhabit a single burrow, or, as is more likely, we were only able to see and count the most obvious and intact burrows in the cores.

The laboratory measurements showed that even when worms were present in burrows, hydraulic conductivity of the sediment was increased. We hypothesize that this is due to the length of the worms (about $10 \mathrm{~cm}$ long) in comparison to the length of the burrows (up to $50 \mathrm{~cm}$ long); a worm does not occupy its entire burrow, which allows water to quickly move through the empty sections of the burrows. The degree of the worm's ability to obstruct flow (or enhance it by irrigation and pumping) through the burrows, as well as its vertical movements within them, may have an effect on hydraulic conductivity as well.

If permeable tube linings (Aller 1983) can affect bioirrigation (Meysman et al. 2005), and tube building itself alters the properties of the sediment between burrows (Jones \& Jago 1993), the spatial relationship of burrows will be important to hydraulic conductivity. Selective feeding, a well-studied adaptation of many deposit feeders, may alter particle size distribution through removal of fine particles or pelletization of the sediment (Volkenborn et al. 2007), either of which would increase permeability. However, Quintana et al. (2007) found that Heteromastus filiformis, a head-down deposit feeder, increased bulk sediment porosity, while Marenzelleria viridis, a surface deposit feeder, had no effect on porosity. This suggests that the increase in hydraulic conductivity we observed due to $M$. viridis burrows (Fig. 7) is not a function of selective feeding on fine particles changing bulk porosity of sediment, but rather an effect due to the burrows themselves.

Because of their effect on the physical properties of the system, deep burrow builders like Marenzelleria viridis should be considered hydraulic 'ecosystem engineers' (Jones et al. 1994) at Cape Henlopen. Effects of bioturbation have been tied to changes in soil hydraulic conductivity in intertidal (Volkenborn et al. 2007), terrestrial (Sobieraj et al. 2002), and freshwater systems (Nogaro et al. 2006), but, to our knowledge, we are the first to propose this kind of interaction in connection with groundwater discharge to marine systems.

We would expect other estuarine sites with fresh groundwater discharge to have similar community responses even if they are composed of species other than those we observed. The magnitude of the effect on hydraulic conductivity is more likely to be site dependent, however. In situations in which sediments have low hydraulic conductivity (e.g. fine sands or silts, or poorly sorted), then the presence of vertical tubes may have a larger effect relatively. In summary, our data describe interactions between the distribution of organisms and the hydrological properties of the sediment, providing a mechanism whereby the ecological complexity of soft-bottom intertidal habitats may be driven and further enhanced by submarine groundwater discharge.

Acknowledgements. We thank W. J. Ullman, T. McKenna, D. Dauer, and T. Straza for valuable comments and S. Gardiner for assistance in the laboratory. M. Steinberg, T. Moore, M. Strom, J. Ossolinski, J. Brown, L. Holm, and E. McDowell participated in field sampling. We are grateful to 3 anonymous reviewers whose comments improved this manuscript. This work was funded primarily by the University of Delaware Sea Grant College Grant R/ME-31 to W. J. Ullman and D.C.M. Additional support was provided by a Sea Grant Aquatic Nuisance Species grant to D.C.M.

\section{LITERATURE CITED}

Aller RC (1983) The importance of the diffusive permeability of animal burrow linings in determining marine sediment chemistry. J Mar Res 41:299-322

> Anderson MJ, Ford RB, Feary DA, Honeywill C (2004) Quantitative measures of sedimentation in an estuarine system and its relationship with intertidal soft-sediment infauna. Mar Ecol Prog Ser 272:33-48

Attrill MJ (2002) A testable linear model for diversity trends in estuaries. J Anim Ecol 71:262-269

Attrill MJ, Rundle SD (2002) Ecotone or ecocline: ecological boundaries in estuaries. Estuar Coast Shelf Sci 55:929-936

Bastrop R (1997) Where did Marenzelleria spp. (Polychaeta: Spionidae) in Europe come from? Aquat Ecol 31:119-136

Bianchi TS (1988) Feeding ecology of subsurface deposit feeder Leitoscoloplos fragilis Verril. 1. Mechanism affecting particle availability on intertidal sandflat. J Exp Mar Biol Ecol 115:79-97

Bock MJ, Miller DC (1995) Storm effects on particulate food resources on an intertidal sandflat. J Exp Mar Biol Ecol 187:81-101

Bock MJ, Miller DC (1999) Particle selectivity, gut volume, and the response to a step change in diet for deposit-feeding polychaetes. Limnol Oceanogr 44:1132-1138 
Bokuniewicz H, Buddemeier R, Maxwell B, Smith C (2003) The typological approach to submarine groundwater discharge (SGD). Biogeochemistry 66:145-158

Brazeiro A, Defeo O (1996) Macroinfauna zonation in microtidal sandy beaches: Is it possible to identify patterns in such variable environments? Estuar Coast Shelf Sci 42:523-536

Brown B (1979) The distribution and biology of Scoloplos fragilis (Orbiniidae: Polychaeta) on a tidal flat, Cape Henlopen, Lewes, Delaware. University of Delaware, Lewes, DE

Clarke KR, Gorley RN (2001) PRIMER v5: user manual/tutorial. PRIMER-E Ltd., Plymouth Marine Laboratory, Plymouth

Clarke KR, Warwick RM (1994) Change in marine communities: an approach to statistical analysis and interpretation. Plymouth Marine Laboratory, Plymouth

Dale RK, Miller DC (2007) Spatial and temporal patterns of salinity and temperature at an intertidal groundwater seep. Estuar Coast Shelf Sci 72:283-298

Fernandes RSR, Soares-Gomes A (2006) Community structure of macrobenthos in two tropical sandy beaches with different morphodynamic features, Rio de Janeiro, Brazil. Mar Ecol 27:160-169

Fetter CW (2001) Applied hydrogeology. Prentice-Hall, Upper Saddle River, NJ

Gimenez L, Borthagaray AI, Rodriguez M, Brazeiro A, Dimitriadis C (2005) Scale-dependent patterns of macrofaunal distribution in soft-sediment intertidal habitats along a largescale estuarine gradient. Helgol Mar Res 59:224-236

Gray JS (2000) The measurement of marine species diversity, with an application to the benthic fauna of the Norwegian continental shelf. J Exp Mar Biol Ecol 250:23-49

Hays RL, Ullman WJ (2007) Direct determination of total and fresh groundwater discharge and nutrient loads from a sandy beachface at low tide (Cape Henlopen, Delaware). Limnol Oceanogr 52:240-247

> Holland AF, Shaughnessy AT, Hiegel MH (1987) Long-term variation in mesohaline Chesapeake Bay macrobenthosspatial and temporal patterns. Estuaries 10:227-245

Hyland JL, Balthis WL, Posey MH, Hackney CT, Alphin TD (2004) The soft-bottom macrobenthos of North Carolina estuaries. Estuaries 27:501-514

Jones CG, Lawton JH, Shachak M (1994) Organisms as ecosystem engineers. Oikos 69:373-386

Jones SE, Jago CF (1993) In situ assessment of modification of sediment properties by burrowing invertebrates. Mar Biol 115:133-142

Jorcin A (1999) Temporal and spatial variability in the macrozoobenthic community along a salinity gradient in the Castillos Lagoon (Uruguay). Arch Hydrobiol 146:369-384

Kamermans P, Hamminga MA, Tack JF, Mateo MA and others (2002) Groundwater effects on diversity and abundance of lagoonal seagrasses in Kenya and on Zanzibar Island (East Africa). Mar Ecol Prog Ser 231:75-83

Kohout FA, Kolipinski MC (1967) Biological zonation related to groundwater discharge along the shore of Biscayne Bay, Miami, Florida. In: Lauff GH (ed) Estuaries, Vol 83. AAAS Publ., Washington, DC, p 488-499

Lirman D, Orlando B, Macia S, Manzello D, Kaufman L, Biber P, Jones T (2003) Coral communities of Biscayne Bay, Florida and adjacent offshore areas: diversity abundance, distribution, and environmental correlates. Aquat Conserv: Mar Freshw Ecosyst 13:121-135

Logan DT, Maurer D (1975) Diversity of marine invertebrates in a thermal effluent. J Water Pollut Control Fed 47: 515-523

McLachlan A, Jaramillo E (1995) Zonation on sandy beaches. Oceanogr Mar Biol Annu Rev 33:305-335

Meysman FJR, Galaktionov ES, Middelburg JJ (2005) Irriga-

Editorial responsibility: Lisa Levin,

La Jolla, California, USA tion patterns in permeable sediments induced by burrow ventilation: a case study of Arenicola marina. Mar Ecol Prog Ser 303:195-212

Miller DC (1992) Response of Saccoglossus kowalevskii (Phylum Hemichordata, Class Enteropneusta) to changes in diet. Mar Ecol Prog Ser 87:41-54

> Miller DC, Ullman WJ (2004) Ecological consequences of groundwater discharge to Delaware Bay, USA. Ground Water 42:959-970

Moore CG (1979) Zonation of psammolittoral harpacticoid copepods around the Isle-of-Man. J Mar Biol Assoc UK 59: 711-724

Muir CL (2002) Rates and patterns of sediment deposition and erosion on sandflats in Delaware Bay: implications for dredge-material disposal and beach nourishment projects. University of Delaware, Lewes

Nogaro G, Mermillod-Blondin F, Francois-Carcaillet F, Gaudet JP, Lafont M, Gibert J (2006) Invertebrate bioturbation can reduce the clogging of sediment: an experimental study using infiltration sediment columns. Freshw Biol 51:1458-1473

Nordstrom KF (1992) Estuarine beaches. Elsevier Applied Science, New York

Qian PY (1999) Larval settlement of polychaetes. Hydrobiologia 402:239-253

Quinn GP, Keough MJ (2006) Experimental design and data analysis. Cambridge University Press, New York

> Quintana CO, Tang M, Kristensen E (2007) Simultaneous study of particle reworking, irrigation transport and reaction rates in sediment bioturbated by the polychaetes Heteromastus and Marenzelleria. J Exp Mar Biol Ecol 352: 392-406

Sharp JH, Culberson CH, Church TM (1982) The chemistry of the Delaware Estuary. General considerations. Limnol Oceanogr 27:1015-1028

Sobieraj JA, Elsenbeer H, Coelho RM, Newton B (2002) Spatial variability of soil hydraulic conductivity along a tropical rainforest catena. Geoderma 108:79-90

Ullman WJ, Chang B, Miller DC, Madsen JA (2003) Groundwater mixing, nutrient diagenesis, and discharges across a sandy beachface, Cape Henlopen, Delaware (USA). Estuar Coast Shelf Sci 57:539-552

- Volkenborn N, Hedtkamp SIC, van Beusekom JEE, Reise K (2007) Effects of bioturbation and bioirrigation by lugworms (Arenicola marina) on physical and chemical sediment properties and implications for intertidal habitat succession. Estuar Coast Shelf Sci 74:331-343

- Weisberg SB, Dauer DM, Schaffner LC, Diaz RJ, Frithsen JB (1997) An estuarine benthic index of biotic integrity (B-IBI) for Chesapeake Bay. Estuaries 20:149-156

Ysebaert T, Meire P, Herman PMJ, Verbeek H (2002) Macrobenthic species response surfaces along estuarine gradients: prediction by logistic regression. Mar Ecol Prog Ser 225:79-95

Ysebaert T, Herman PMJ, Meire P, Craeymeersch J, Verbeek H, Heip CHR (2003) Large-scale spatial patterns in estuaries: estuarine macrobenthic communities in the Schelde estuary, NW Europe. Estuar Coast Shelf Sci 57:335-355

Zektzer IS, Ivanov VA, Meskheteli AV (1973) The problem of direct groundwater discharge to the seas. J Hydrol 20: $1-36$

Zettler ML, Schiedek D, Bobertz B (2007) Benthic biodiversity indices versus salinity gradient in the southern Baltic Sea. Mar Pollut Bull 55:258-270

Zipperle A, Reise K (2005) Freshwater springs on intertidal sand flats cause a switch in dominance among polychaete worms. J Sea Res 54:143-150

Submitted: August 30, 2005; Accepted: February 12, 2008

Proofs received from author(s): June 26, 2008 